\title{
Telemedicine: Still a lot of static
}

The rapid growth of information and communication technologies should be pushing the envelope of medical practice. It isn't hard to imagine physicians examining their patients virtually if not physically, doctors consulting each other at a distance but in real time, and calling up a patient's complete medical history with a simple keystroke. Indeed, such things were imagined even before the first video images were transmitted (see picture). But the fact is that telemedicine is simply not ready for prime time, despite years of hype and hope.

A committee report released 8 October by the US institute of Medicine suggests that a major roadblock to telemedicine's estab-
lishment is the haphazard way new technologies are being ap- plied. Sometimes the latest thing isn't the greatest thing, and to- day's must-have electronic toy is tomorrow's paperweight. Thus the Institute committee's report at- tempts to establish a framework

\section{IMAGE \\ UNAVAILABLE FOR COPYRIGHT REASONS} that can be used by institutions or individual practitioners to evaluate specific telemedicine applications. The framework should take into account not only if the technology provides a necessary function now, but also if it is reliable, usable in the future, and adaptable to change.

As new technological tools tend to be more expensive, there is increased pressure from insurance and health care management orga- nizations to justify such expenses. This marketplace dynamic was a major impetus for the Institute of Medicine to appoint a committee to look at telemedicine issues. Thus the committee concentrated on the evaluative process, rather than on specific technologies. "Its goal ... was not to promote telemedicine as such, but to encourage the development of good information about telemedicine for those making decisions that affect the quality of American health care, how much it costs, and who has access to it," said committee chair John R. Ball, who is also president and chief ex-

ecutive officer of Pennsylvania Hospital in Philadelphia.

In addition to emphasizing the need for careful evaluation before implementation, the committee report also calls on federal and state governments to be more actively involved in evaluating new technologies, and asks technology suppliers to work toward standardization of the software and hardware used in various applications.

F.R.S.

\section{Lasker Awards and Nobel Prizes given}

With the falling of leaves in the northern hemisphere comes the tossing of laurels, and the Nobel Prizes and the Lasker Awards are the most coveted.

The 1996 Nobel Prize in Physiology or Medicine, and its purse of US\$1.12 million dollars, went to Peter Doherty of St. Jude Children's Research Hospital in Memphis, Tennessee, and Rolf Zinkernagel of the University of Zurich, Switzerland. The award was given for research the two men pursued together in Canberra, Australia, which laid the foundation for understanding how immune cells "recognize" foreign proteins and activate a response. Awards, which often presage the Nobels (as in the case of Doherty and Zinkernagel Nature Medicine 1, 1111; 1995), were presented as follows. The Basic Medical Re-
The 1996 Albert Lasker Medical Research
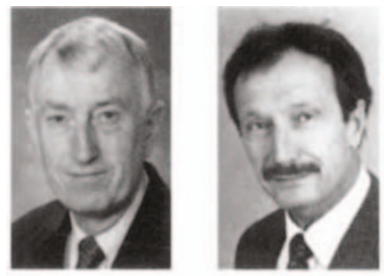

Nobelists Doherty, Zinkernagel (above). Lasker group photo: (standing left-to-right) Murad, Smith, Furchgott, Zamecnik and Anderson; (seated) Robbins and Schneerson.

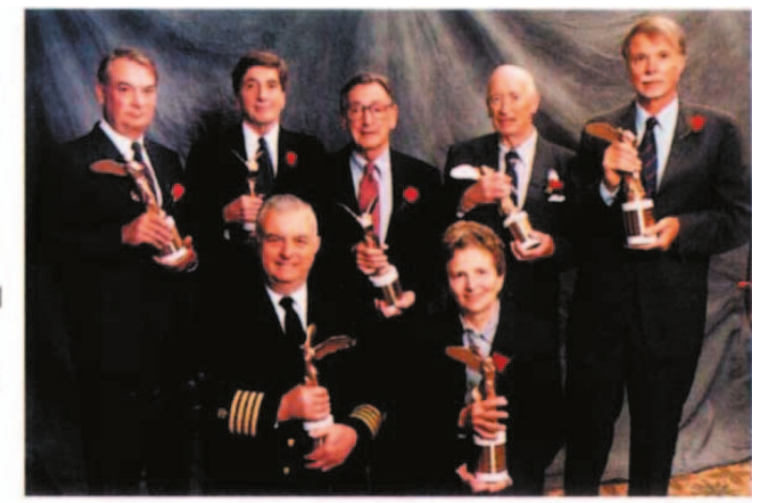

search Award went to Robert Furchgott of the State University of New York Health Science Center at Brooklyn and Ferid Murad, former president and CEO of Molecular Geriatrics Corporation of Lake Bluff, Illinois, for work leading to the understanding of the role of nitric oxide in health and disease. The Lasker Clinical Medical Research Award went to four sci-

\section{Friesen gets second term at helm of Canada's MRC}

On September 27, Canadian Health Minister David Dingwall announced that he was appointing Henry Friesen to a second five-year term as President of the Medical Research Council of Canada (MRC). Friesen was previously the head of the department of physiology and a professor of medicine at the University of Manitoba.

An endocrinologist by training, Friesen is best known outside of Canada for his discovery of the human hormone prolactin, which has led to successful treatment of some forms of reproductive disorders. Friesen has also been president of the Canadian Society for Clinical Investigation and the National Cancer Institute of Canada. entists who developed the vaccine for $\mathrm{He}$ mophilus influenzae type b: Porter Anderson of the University of Rochester School of Medicine, New York; David Smith, president of the David H. Smith Foundation in New York City; and John Robbins and Rachel Schneerson, both from the National Institute of Child Health and Human Development in Bethesda, Maryland.

A new Lasker Award initiated this year, Special Achievement in Medical Science, was given to Paul Zamecnik of the Worcester Foundation for Biomedical Research in Shrewsbury, Massachusetts. Zamecnik and his research team is credited with defining the biochemistry of amino acid activation and protein assembly, tools that were crucial to unlocking the genetic code.

F.R.S. 